NOTA

\title{
POTENTIAL ACIDITY ESTIMATED BY SMP pH IN SOILS OF THE STATE OF PARÁ(1)
}

\author{
Marcos André Piedade Gama ${ }^{(2)}$, Gilson Sergio Bastos de Matos ${ }^{(3)}$, George Rodrigues da \\ Silva $^{(4)}$, Edilson Carvalho Brasil ${ }^{(5)}$ \& Otiniel Ferreira Nunes ${ }^{(6)}$
}

\begin{abstract}
SUMMARY
The use of SMP pH to estimate the potential acidity $(\mathrm{H}+\mathrm{Al})$ is more practical than the method of $0.5 \mathrm{~mol} \mathrm{~L}^{-1}$ calcium acetate for routine laboratory analyses. The objective was to fit an equation to estimate the $\mathrm{H}+\mathrm{Al}$ from SMP pH values of soils of the State of Pará. From various regions of the state, 177 soil samples were collected, in which the SMP pH was determined in $0.01 \mathrm{~mol} \mathrm{~L}^{-1} \mathrm{CaCl}_{2}$ solution and $\mathrm{H}+\mathrm{Al}$ in $0.5 \mathrm{~mol} \mathrm{~L}^{-1}$ calcium acetate and the results were related by regression analysis. The equation $\mathrm{H}+\mathrm{Al}=77.77+20.61 \mathrm{SMP} \mathrm{pH}-1.435 \mathrm{SMP} \mathrm{pH}^{2}\left(\mathrm{R}^{2}=0.90\right)$ expressed the $\mathrm{H}+\mathrm{Al}$ values (in $\mathrm{cmol}_{\mathrm{c}} \mathrm{dm}^{-3}$ ) best. When the SMP pH values were used in equations referring to other regions or states in Brazil, the $\mathrm{H}+\mathrm{Al}$ values were over- or underestimated. The potential acidity in soils of Pará can be estimated by the method of SMP pH.
\end{abstract}

Index terms: $\mathrm{H}+\mathrm{Al}$, soil analysis, Amazon, soil fertility.

\section{RESUMO: ACIDEZ POTENCIAL ESTIMADA PELO MÉTODO DO $p H$ SMP EM SOLOS DO ESTADO DO PARÁ}

O uso do pH SMP na estimativa da acidez potencial $(H+A l)$ apresenta maior praticidade em relação ao método do acetato de cálcio $0,5 \mathrm{~mol} \mathrm{~L}^{-1}$ para laboratórios de rotina. Objetivouse com este trabalho ajustar uma equação para estimar $H+A l$, a partir dos valores de $\mathrm{pH}$ SMP de solos do Estado do Pará. Foram utilizadas 177 amostras de solo das várias regiões do

\footnotetext{
(1) Received for publication on March 15, 2012 and approved on November 20, 2012.

(2) Professor, Federal Rural University of Amazon - UFRA. Av. Presidente Tancredo Neves, 2501, Bairro Montese. CEP 66.077901 Belém (PA). E-mail: marcos.gama@ufra.edu.br

(3) Doctoral student of Agronomy (PPGA) - UFRA. E-mail: gilsonsbm@ufra.edu.br

(4) Professor, UFRA. E-mail: george.silva@ufra.edu.br

(5) Researcher at Embrapa Eastern Amazon. Travessa Enéas Pinheiro, s/n, Bairro Marco. CEP 66095-100 Belém (PA). E-mail: brasil@cpatu.embrapa.br

(6) Master student at PPGA - UFRA. E-mail: otiniel.nunes@ufra.edu.br
} 


\begin{abstract}
estado, em que se realizaram as determinações de $\mathrm{pH} \mathrm{SMP}$, em solução de $\mathrm{CaCl}_{2} 0,01 \mathrm{~mol} \mathrm{~L}^{-1}$, e $H+A l$, em acetato de cálcio $0,5 \mathrm{~mol} \mathrm{~L}^{-1}$; os resultados foram relacionados por análise de regressão. A equação $H+A l=77.77+20.61 S M P p H-1.435 S M P p H^{2}\left(R^{2}=0,90\right)$ foi a que melhor expressou os valores $H+A l$ em $\mathrm{cmol}_{c} \mathrm{dm}^{-3}$. Quando se utilizaram os valores de $\mathrm{pH} S \mathrm{SMP}$ em equações de outras regiões ou estados brasileiros, ocorreu subestimativa ou superestimava dos valores de $H+A l$. A acidez potencial pode ser estimada pelo método do pH SMP em solos paraenses.
\end{abstract}

Termos para indexação: $H+A l$, análise de solo, Amazônia, fertilidade do solo.

\section{INTRODUCTION}

The lime requirement can be determined by the method of Al neutralization, with or without increasing $\mathrm{Ca}$ and $\mathrm{Mg}$ concentrations, or inferred from base saturation, based on the cation exchange capacity (CEC) at $\mathrm{pH}$ 7.0. This variable, in turn, must include the value of potential acidity $(\mathrm{H}+\mathrm{Al})$ plus the exchangeable bases (Kaminski et al., 2007).

In Brazil, the potential acidity is most commonly determined by the method of $0.5 \mathrm{~mol} \mathrm{~L}^{-1}$ calcium acetate at $\mathrm{pH} 7.0$ in laboratories. However, the method has some drawbacks such as: the procedure is timeconsuming for involving the two steps extraction and titration (Silva et al., 2006), the quality of most of the calcium acetate available for purchase is low (Pavan et al., 1996); the turning point of organic-matter-rich soils is hard to detect (Silva et al., 2000), and the $\mathrm{H}+$ $\mathrm{Al}$ levels in soils with a $\mathrm{pH}$ range of $6.5-7.0$ are underestimated, due to the poor buffering of calcium acetate in soils with this acidity degree (Raij, 1997).

The potential acidity can be estimated by the SMP $\mathrm{pH}$ buffer method, which is strongly correlated with the $\mathrm{H}+\mathrm{Al}$ values determined by the calcium acetate method (Quaggio \& Raij, 2001; Moreira et al., 2004; Chaves et al., 2007). The SMP pH corresponds to the equilibrium $\mathrm{pH}$ obtained from the soil supernatant with the SMP buffer solution; the method was first developed by Shoemaker et al. (1961) to determine the lime requirement. In recent years, it has been widely tested and even used in routine analysis to estimate the potential acidity of soils in several Brazilian states (Sambatti et al., 2003; Pereira et al., 2006; Silva et al., 2006).

The SMP buffer solution contains $p$-nitrophenol and potassium chromate, classified as toxic and unhealthy substances, requiring special care with handling and waste disposal (Toledo et al., 2012). However, it is convincingly simple and convenient for routine analyses of $\mathrm{H}+\mathrm{Al}$ of the $\mathrm{CEC}$ at $\mathrm{pH} 7.0$ (Raij et al., 1997), as well as for recommendations of lime rates, and it is commonly used in the States of Santa Catarina and Rio Grande do Sul (Tedesco et al., 1995).

Despite the above advantages, the equations to estimate the potential acidity from the SMP $\mathrm{pH}$ should be regionally adjusted, since the results are influenced by the soil chemical, physical and mineralogical properties (Pereira et al., 2006). For the state of São
Paulo, the fitted equation corresponded to $\ln (\mathrm{H}+\mathrm{Al})$ $=7.76-1.053 \mathrm{SMP} \mathrm{pH}\left(\mathrm{R}^{2}=0.99\right)$, for Mato Grosso do Sul to $\ln (\mathrm{H}+\mathrm{Al})=8.086-1.062 \mathrm{SMP} \mathrm{pH}\left(\mathrm{R}^{2}=0.96\right)$, $\left(\mathrm{R}^{2}=0.96\right)$, for Santa Catarina to $(\mathrm{H}+\mathrm{Al})=3.9014-$ 0.391 SMP $\left(\mathrm{R}^{2}=0.90\right)$, for Pernambuco to $(\mathrm{H}+\mathrm{Al})=$ $38.448+8.4855 \mathrm{SMP} \mathrm{pH}-0.4837 \mathrm{SMP} \mathrm{pH}\left(\mathrm{R}^{2}=0.90\right)$ and for the Amazon region to $\left(\mathrm{CaCl}_{2} \mathrm{pH}\right): \mathrm{H}+\mathrm{Al}=$ 30.155 - 3.834 SMP pH $\left(\mathrm{R}^{2}=0.91\right)$, which shows the peculiarities of the soils in regions and states of Brazil (Silva et al., 2006).

The purpose was to fit a regression equation to estimate the potential acidity by the SMP $\mathrm{pH}$ value of representative soils of the State of Pará, with a view to introduce this method in routine analyses in regional laboratories.

\section{MATERIAL AND METHODS}

This study was developed in the laboratory of soil chemistry, Federal Rural University of Amazonia (UFRA) in Belém, Pará. From several municipalities, representing all mesoregions of Pará (Metropolitan Belém, Northeast, Southeast, Lower Amazon, and Southwest), 177 soil samples were taken from the 0$20 \mathrm{~cm}$ layer The samples were separated into the following texture classes (Embrapa, 2006): sandy (28), medium (50), clayey (68) and very clayey texture (31). The $\mathrm{pH}$ range in $\mathrm{H}_{2} \mathrm{O}$ was $3.72-7.36$, and the content of organic carbon was 2.27-38.59 $\mathrm{g} \mathrm{kg}^{-1}$ and $100-800 \mathrm{~g}$ $\mathrm{kg}^{-1}$ of clay.

The analyses consisted of determining $\mathrm{H}+\mathrm{Al}$ by the method of calcium acetate, $\mathrm{SMP} \mathrm{pH} \mathrm{CaCl}$ and $\mathrm{pH}$ of each sample in triplicate. The potential acidity was determined by extraction with $0.5 \mathrm{~mol} \mathrm{~L}^{-1}$ calcium acetate at $\mathrm{pH} 7.0$ and by titration with $0.025 \mathrm{~mol} \mathrm{~L}^{-1}$ $\mathrm{NaOH}$. For this purpose, $10 \mathrm{~cm}^{3}$ of air-dried fine earth was filled in a $250 \mathrm{~mL}$ Erlenmeyer flask with $100 \mathrm{~mL}$ of extraction solution. After stirring the earth-acetate suspension for $15 \mathrm{~min}$ and left to stand for $16 \mathrm{~h}$, a 25 $\mathrm{mL}$ aliquot of liquid supernatant was taken, and three drops of phenolphthalein alcohol solution were added to determine $\mathrm{H}+\mathrm{Al}$ by $\mathrm{NaOH}$ titration.

For the $\mathrm{pH}$ in $0.01 \mathrm{~mol} \mathrm{~L}^{-1} \mathrm{CaCl}_{2}$, a proportion of 1:2.5 for soil: solution was used, assessed in suspension (Embrapa, 1997). The SMP pH was determined according to Quaggio \& Raij (2001), and to this end, 
after reading the $\mathrm{CaCl}_{2} \mathrm{pH}, 5.0 \mathrm{~mL}$ of SMP buffer solution was added at $\mathrm{pH} 7.5$ and stirred for $15 \mathrm{~min}$ at $220 \mathrm{rpm}$. After standing for $60 \mathrm{~min}$, the equilibrium $\mathrm{pH}$ was read in the soil- SMP solution.

The SMP $\mathrm{pH}$ and $\mathrm{H}+\mathrm{Al}$ determined by the calcium acetate method were related and statistically adjusted by regression analysis, selecting the equation with the best coefficient of determination $\left(\mathrm{R}^{2}\right)$. In addition, a correlation analysis of the $\mathrm{SMP} \mathrm{pH}$ and $\mathrm{CaCl}_{2} \mathrm{pH}$ was performed.

\section{RESULTS AND DISCUSSION}

The values of $\mathrm{H}+\mathrm{Al}$ determined by the calcium acetate method varied between 3.10 and $14.9 \mathrm{cmol}_{\mathrm{c}}$ $\mathrm{dm}^{-3}$, while the SMP $\mathrm{pH}$ ranged from 4.58 to 7.56. The relationship between these variables was described by the following equation: $\mathrm{H}+\mathrm{Al}\left(\mathrm{cmol}_{\mathrm{c}} \mathrm{dm}^{-3}\right)=77.77$ $+20.61 \mathrm{SMP} \mathrm{pH}-1.435 \mathrm{SMP} \mathrm{pH}^{2}\left(\mathrm{R}^{2}=0.90\right)($ Figure 1). These results demonstrated that the SMP $\mathrm{pH}$ increase was accompanied by a decrease in the $\mathrm{H}+$ $\mathrm{Al}$ values in the soil samples from Pará. Similar inverse relationships were found for soils in the State of Pernambuco (Nascimento, 2000), in the North of Minas Gerais (Silva et al., 2002), in northeastern Pará (Gama et al., 2002) and in a microregion of homogeneous marsh in Paraiba (Chaves et al., 2007).

The adjustment equation between the data of potential acidity by the method of calcium acetate and the SMP $\mathrm{pH}$ added to the $\mathrm{CaCl}_{2} \mathrm{pH}$ solution after shaking obtained in this study and the equations of other states or regions of Brazil, can be compared based on six fixed values ranging from 4.5 to 7.5 (Table 1). In this SMP $\mathrm{pH}$ range, the $\mathrm{Al}+\mathrm{H}$ estimated for the soils of the State of Pará were close to those found for northeastern Pará (Gama et al., 2002) and the

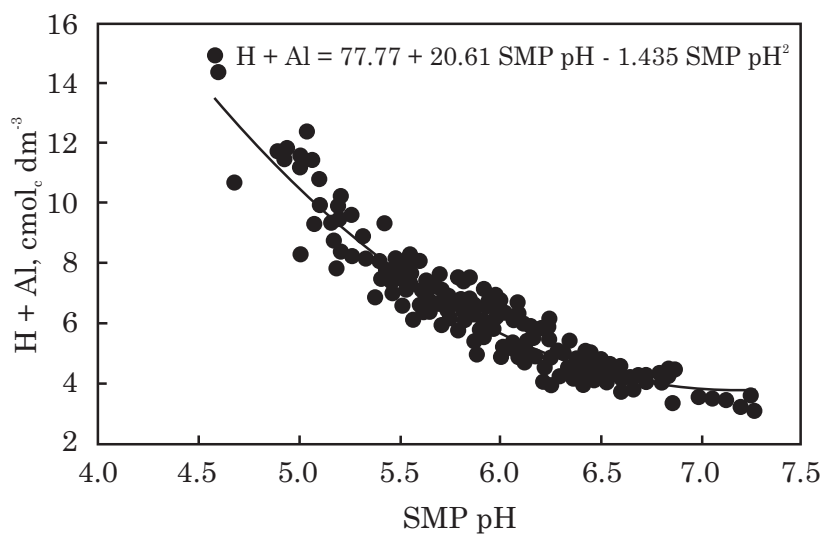

Figure 1. Relationship between the $\mathrm{H}+\mathrm{Al}$ concentrations determined by the method of calcium acetate and SMP $\mathrm{pH}$ in representative soil samples of the State of Pará * Significant by regression analysis $(\mathbf{p}<0.05)$.
Table 1. Estimation of potential acidity $(\mathrm{H}+\mathrm{Al})$ versus SMP pH of soils of the State of Pará

\begin{tabular}{cccccc}
\hline SMP pH & $\mathbf{H}+\mathbf{A l}$ & $\mathbf{S M P} \mathbf{p H}$ & $\mathbf{H}+\mathbf{A l}$ & $\mathbf{S M P} \mathbf{p H}$ & $\mathbf{H}+\mathbf{A l}$ \\
\hline & $\mathrm{cmol}_{\mathrm{c}} \mathrm{dm}^{-3}$ & & $\mathrm{cmol}_{\mathrm{c}} \mathrm{dm}^{-3}$ & \multicolumn{3}{c}{$\mathrm{cmol}_{\mathrm{c}} \mathrm{dm}^{-3}$} \\
4.50 & 14.08 & 5.45 & 8.07 & 6.40 & 4.64 \\
4.55 & 13.70 & 5.50 & 7.82 & 6.45 & 4.54 \\
4.60 & 13.33 & 5.55 & 7.59 & 6.50 & 4.43 \\
4.65 & 12.96 & 5.60 & 7.36 & 6.55 & 4.34 \\
4.70 & 12.60 & 5.65 & 7.13 & 6.60 & 4.25 \\
4.75 & 12.25 & 5.70 & 6.92 & 6.65 & 4.17 \\
4.80 & 11.90 & 5.75 & 6.71 & 6.70 & 4.10 \\
4.85 & 11.57 & 5.80 & 6.51 & 6.75 & 4.03 \\
4.90 & 11.24 & 5.85 & 6.31 & 6.80 & 3.98 \\
4.95 & 10.91 & 5.90 & 6.12 & 6.85 & 3.93 \\
5.00 & 10.60 & 5.95 & 5.94 & 6.90 & 3.88 \\
5.05 & 10.29 & 6.00 & 5.77 & 6.95 & 3.84 \\
5.10 & 9.98 & 6.05 & 5.60 & 7.00 & 3.82 \\
5.15 & 9.69 & 6.10 & 5.45 & 7.05 & 3.79 \\
5.20 & 9.40 & 6.15 & 5.29 & 7.10 & 3.78 \\
5.25 & 9.12 & 6.20 & 5.15 & 7.15 & 3.77 \\
5.30 & 8.85 & 6.25 & 5.01 & 7.20 & 3.77 \\
5.35 & 8.58 & 6.30 & 4.88 & 7.25 & 3.77 \\
5.40 & 8.32 & 6.35 & 4.76 & 7.30 & 3.79 \\
\hline & & & & & \\
\hline
\end{tabular}

Amazonas (Moreira et al, 2004). However, the equations for other states such as São Paulo (Quaggio et al., 1985), Minas Gerais (Corrêa et al., 1985), Mato Grosso do Sul (Maeda et al., 1997), Rio de Janeiro (Pereira et al., 1998), Northwestern Paraná (Sambatti et al., 2003), and for the Cerrado region (Sousa et al., 1989), compared with the one obtained in this study, mostly tended to overestimate the potential acidity for more acidic soil $(\mathrm{pH}<5.5)$ and to underestimate more alkaline soil $(\mathrm{pH}>6.0)$. These results show the similarity between the soils of the Amazon, and differences between them and soils of other regions (Table 2).

The difference between the equation in this study and equations from other regions and states confirmed the importance of a regional adjustment of the SMP $\mathrm{pH}$ method. This fact is related to the different chemical, physical and mineralogical properties of the soils that influenced the buffering (Escosteguy \& Bissani, 1999; Silva et al., 2002).

Another important aspect of the use of SMP buffer is that an accurate estimation of the $\mathrm{H}+\mathrm{Al}$ concentration is imperative, since these values underlie the calculation of CEC at $\mathrm{pH} 7.0(\mathrm{~T})$, which is used to calculate base saturation (V). Both variables are used to evaluate the lime requirement by the base saturation method, which should not be overestimated, to avoid additional costs with liming, or underestimated, which would reduce the rate and effect of neutralization by liming. 
Table 2. Comparison of estimates of $\mathrm{H}+\mathrm{Al}$ levels in soils in the State of Pará, with SMP pH between 4.5 and 7.3, based on equations adapted for different states and regions of Brazil

\begin{tabular}{|c|c|c|c|c|c|c|c|c|}
\hline \multirow[t]{2}{*}{ Region or state } & \multirow[t]{2}{*}{ Reference } & \multicolumn{7}{|c|}{ SMP pH determined in $\mathrm{CaCl}_{2}$} \\
\hline & & 4.5 & 5.0 & 5.5 & 6.0 & 6.5 & 7.0 & 7.5 \\
\hline & & \multicolumn{7}{|c|}{$-\mathrm{H}+\mathrm{Al}, \mathrm{cmol}_{\mathrm{c}} \mathrm{dm}^{-3}$} \\
\hline São Paulo & Quaggio et al. (1985) & 20.52 & 12.12 & 7.16 & 4.23 & 2.50 & 1.48 & 0.87 \\
\hline Minas Gerais & Corrêa et al. (1985) & 21.43 & 12.3 & 7.06 & 4.06 & 2.33 & 1.33 & 0.77 \\
\hline Cerrados & Sousa et al. (1989) & 18.41 & 10.79 & 6.33 & 3.71 & 2.17 & 1.27 & 0.75 \\
\hline Mato Grosso Sul & Maeda et al. (1997) & 27.37 & 16.1 & 9.46 & 5.57 & 3.27 & 1.92 & 1.13 \\
\hline Rio de Janeiro & Pereira et al. (1998) & 23.50 & 14.11 & 8.44 & 5.09 & 3.05 & 1.83 & 1.10 \\
\hline Northeastern Paraense & Gama et al. (2002) & 14.05 & 10.11 & 6.82 & 4.17 & 2.17 & 0.82 & 0.12 \\
\hline Northwestern Paraná & Sambatti et al. (2003) & 8.27 & 6.95 & 5.63 & 4.3 & 2.98 & 1.65 & 0.33 \\
\hline Amazonas & Moreira et al. (2004) & 12.90 & 10.98 & 9.06 & 7.15 & 5.23 & 3.31 & 1.40 \\
\hline Pará & present study & 14.08 & 10.60 & 7.82 & 5.77 & 4.43 & 3.82 & 3.84 \\
\hline
\end{tabular}

The equations used to estimate $\mathrm{H}+\mathrm{Al}$ concentrations based on SMP $\mathrm{pH}$ were: $\mathrm{SP}: \ln (\mathrm{H}+\mathrm{Al})=7.76-1.053 \mathrm{SMP}$ pH; MG: $\ln (\mathrm{H}$ $+\mathrm{Al})=8.06-1.111 \mathrm{SMP}$ pH; Cerrados: $\ln (\mathrm{H}+\mathrm{Al})=7.719-1.068 \mathrm{SMP} \mathrm{pH} ; \mathrm{MS}: \ln (\mathrm{H}+\mathrm{Al})=8.086-1.062 \mathrm{SMP} \mathrm{pH} ; \mathrm{RJ}: \ln (\mathrm{H}+$ $\mathrm{Al})=7.75-1.02 \mathrm{SMP}$ pH; Northeastern Pará: $\mathrm{H}+\mathrm{Al}=78.63+20.173 \mathrm{SMP}$ pH -1.3294 SMP pH ${ }^{2}$; Northwestern Paraná: H + Al $=20.1925-2.6484$ SMP pH; Amazonas $\left(\mathrm{CaCl}_{2} \mathrm{pH}\right): \mathrm{H}+\mathrm{Al}=30.155-3.834 \mathrm{SMP} \mathrm{pH}$.

\section{CONCLUSION}

The potential acidity $(\mathrm{H}+\mathrm{Al})\left(\mathrm{in} \mathrm{cmol}_{\mathrm{c}} \mathrm{dm}^{-3}\right)$ of the soils of State of Pará can be estimated by the equation $\mathrm{H}+\mathrm{Al}=77.77+20.61 \mathrm{SMP} \mathrm{pH}-1.435 \mathrm{SMP}$ $\mathrm{pH}^{2}\left(\mathrm{R}^{2}=0.90\right)$.

\section{LITERATURE CITED}

CHAVES, L.H.G.; CHAVES, I.B. \& VASCONCELOS, A.C.F. Estimativa da acidez potencial pelo método do SMP $\mathrm{pH}$ em solos da Microrregião Homogênea Brejo Paraibano. R. Bras. Eng. Agríc. Amb., 11:398-403, 2007.

CORRÊA, J.B.; COSTA, P.C.; LOPES, A.S. \& CARVALHO, J.G. Evaluation of $\mathrm{H}+\mathrm{Al}$ by SMP method. In: CONGRESSO BRASILEIRO DE PESQUISAS CAFEEIRAS, 12., Caxambu, 1985. Anais... Rio de Janeiro, Instituto Brasileiro do Café, 1985. p.111-112.

EMPRESA BRASILEIRA DE PESQUISA AGROPECUÁRIA EMBRAPA. Centro Nacional de Pesquisa de Solos. Manual de métodos de análise de solos. 2.ed. Rio de Janeiro, 1997. p.212.

EMPRESA BRASILEIRA DE PESQUISA AGROPECUÁRIA EMBRAPA. Centro Nacional de Pesquisa de Solos. Sistema brasileiro de classificação de solos. 2.ed. Rio de Janeiro, 2006. 306p.

ESCOSTEGUY, P.A. \& BISSANI, C.A. Estimativa de $\mathrm{H}+\mathrm{Al}$ pelo SMP $\mathrm{pH}$ em solos do Estado do Rio Grande de Sul e de Santa Catarina, R. Bras. Ci. Solo, 23:175-179, 1999.

GAMA, M.A.P.; PROCHNOW, L.I. \& GAMA, J.R.N.F. Estimativa da acidez potencial pelo método SMP em solos ocorrentes no Nordeste Paraense. R. Bras. Ci. Solo, 26:1093-1097, 2002.
KAMINSKI, J.; SILVA, L.S.; CERETTA, C.A. \& RENHEIMER, D.S. Acidez e calagem em solos do sul do Brasil: Aspectos históricos e perspectivas futuras. In: CERETTA, C.A.; SILVA, L.S. \& REICHERT, J.M., eds. Tópicos em ciência do solo. Viçosa, MG, Sociedade Brasileira de Ciência do Solo, 2007. v.5. p.307-332.

MAEDA, S.; KURIHRA, C.H.; HERNANI, L.C.; FABRICIO, A.C. \& SILVA, W.M. Estimativa da acidez potencial, pelo método do SMP $\mathrm{pH}$, em solos do Mato Grosso do Sul. Dourados, Empresa Brasileira de Pesquisa Agropecuária, 1997. p.25. (Boletim de Pesquisa, 3)

MOREIRA, A.; ALMEIDA, M.P.; COSTA, D.G. \& SANTOS, L.S. Acidez potencial pelo método do SMP $\mathrm{pH}$ no Estado do Amazonas. Pesq. Agropec. Bras., 39:89-92, 2004.

NASCIMENTO, C.W.A. Acidez potencial estimada pelo SMP $\mathrm{pH}$ em solos do Estado de Pernambuco. R. Bras. Ci. Solo, 24:679-682, 2000.

PAVAN, M.A.; OLIVEIRA, E.L. \& MIYAZAWA, M. Determinação indireta da acidez extraível do solo $(\mathrm{H}+\mathrm{Al})$ por potenciometria com a solução tampão SMP. Arq. Biol. Tecnol., 39:307-312, 1996.

PEREIRA, M.G.; EBELING, A.G.; VALLADARES, G.S.; ANJOS, L.H.C. \& ESPÍNDULA JÚNIOR, A. Estimativa da acidez potencial pelo método do SMP pH em solos com elevado teor de matéria orgânica. Bragantia, 65:487-493, 2006.

PEREIRA, M.G.; VALLADARES, G.S.; SOUZA, J.M.P.F.; PÉREZ, D.V. \& DOS ANJOS, L.H.C. Estimativa da acidez potencial pelo método do SMP $\mathrm{pH}$ em solos do Estado do Rio de Janeiro. R. Bras. Ci. Solo, 22:159-162, 1998.

QUAGGIO, J.A. \& RAIJ, B.van. Determinação do pH em cloreto de cálcio e da acidez total. In: RAIJ, B.van; ANDRADE, J.C.; CANTARELLA, H. \& QUAGGIO, J.A., eds. Análise química para avaliação da fertilidade de solos tropicais. Campinas, Instituto Agronômico de Campinas, 2001. p.181-188. 
QUAGGIO, J.A.; RAIJ, B.van \& MALAVOLTA, E. Alternative use of the SMP-buffer solution to determine lime requirement of soils. Commun. Soil Sci. Plant Anal., 16:245-260, 1985 .

RAIJ, B.van. Fertilidade do solo e adubação. Piracicaba, Ceres/ Potafos, 1991. 343p.

RAIJ, B.van; CANTARELLA, H.; QUAGGIO, J.A. \& FURLANI, A.M.C., eds. Recomendações de adubação e calagem para o estado de São Paulo. 2.ed. Campinas, Instituto Agronômico/Fundação IAC, 1997. (Boletim Técnico, 100)

SAMBATTI, J.A.; SOUZA JUNIOR, I.G.; COSTA, A.C.S. \& TORMENA, C.A. Estimativa da acidez potencial pelo método do SMP pH em solos da formação Caiuá-Noroeste do Estado do Paraná. R. Bras. Ci. Solo, 27:257-264, 2003.

SHOEMAKER, H.E.; McLEAN, E.O. \& PRATT, P.F. Buffer methods for determining the lime requirement of soils with appreciable amounts of extractable aluminum. Soil Sci. Soc. Am. Proc., 25:274-277, 1961.

SILVA, C.A.; AVELLAR, M.L. \& BERNARDI, A.C.C. Estimativa da acidez potencial pelo SMP pH em solos do Semi-Árido do Nordeste Brasileiro. R. Bras. Ci. Solo, 24:689-692, 2000.
SILVA, E.B.; COSTA, H.A.O. \& FARNEZI, M.M.M. Acidez potencial estimada pelo método do SMP $\mathrm{pH}$ em solos da Região do vale do Jequitinhonha no Estado de Minas Gerais. R. Bras. Ci. Solo, 30:751-757, 2006.

SILVA, E.B.; DIAS, M.S.C.; GONZAGA, E.I.C. \& SANTOS, N.M. Estimativa da acidez potencial pelo SMP $\mathrm{pH}$ em solos da região norte do estado de Minas Gerais. R. Bras. Ci. Solo, 26:561-565, 2002.

SOUSA, D.M.G.; MIRANDA, L.N.; LOBATO, E. \& CASTRO, L.H.R. Métodos para determinar as necessidades de calagem em solos dos cerrados. R. Bras. Ci. Solo, 13:193$198,1989$.

TEDESCO, M.J.; GIANELLO, C.; BISSANI, C.; BOHNEN, B. \& VOLKWEISS, S.J. Análise de solo, plantas e outros materiais. Porto Alegre, Universidade Federal do Rio Grande do Sul, 1995. 174p. (Boletim Técnico, 5)

TOLEDO, J.A.; KAMINSKI, J.; SANTANNA, M.A. \& SANTOS, D.R. Tampão Santa Maria (TSM) como alternativa ao tampão SMP para medição da acidez potencial de solos ácidos. R. Bras. Ci. Solo, 36:427$435,2012$. 